\title{
ERRATUM
}

\author{
G. Havenith · H. O. Nilsson
}

\section{Correction of clothing insulation for movement and wind effects, a meta-analysis}

Published online: 30 October 2004

(C) Springer-Verlag 2004

\section{Eur J Appl Physiol (2004) 92:636-640}

Unfortunately, there was an error is present in Eq. 6. Instead of -0.512 , the constant should be -0.0512 . The correct formula 6 (correction formula for correction of total clothing insulation of cold weather clothing $\left(1.49 \mathrm{clo}<I_{T}<3.46 \mathrm{clo}\right)$, in relation to walking speed $\left(0<w<1.2 \mathrm{~m} . \mathrm{s}^{-1}\right)$, air speed relative to the body $\left(0.4<v_{a r}<18 \mathrm{~m} . \mathrm{s}^{-1}\right)$ and clothing air permeability $(\mathrm{p}: 1$ for garments with impermeable membranes; 50 for densely woven workwear and 1000 for highly permeable garments) should read:

$$
\begin{aligned}
I_{\mathrm{T}, \mathrm{r}}= & {\left[e^{\left\{\left[-0.0512 *\left(v_{\mathrm{ar}}-0.4\right)+0.794 * 10^{-3} *\left(v_{\mathrm{ar}}-0.4\right)^{2}-0.0639 * w\right] * p^{0.1434}\right\}}\right] } \\
& \cdot I_{\mathrm{T}, \text { static }}
\end{aligned}
$$

The online version of the original article can be found at http:// dx.doi.org/10.1007/s00421-004-1113-6

G. Havenith $(\bowtie)$

Department of Human Sciences, Loughborough University, Ashby Road, Loughborough, LE11 3TU, UK

E-mail: g.havenith@1boro.ac.uk

Tel.: + 44-1509-223031

Fax: + 44-1509-223940

H. O. Nilsson

Division for Indoor Climate, Centre for Built Environment, Gävle University, 80176 Gävle, Sweden 